\title{
Democratic maturity, external efficacy, and participation in elections: towards macro-micro interaction
}

\author{
Michal Nový1, *, Tomáš Katrňák \\ 1 Masaryk University, Czech Republic \\ * E-Mail:273880@mail.muni.cz
}

\begin{abstract}
This paper analyzes how the age of a democracy matters when explaining voter turnout. It proposes that democratic maturity might influence the probability of casting a ballot not only directly, but at the same time, as an amplifier of the effects of individual-level predictors of voting. From an array of variables that might be responsible for raising or lowering one's probability of voting, this study emphasizes that the impact of a sense of external efficacy can be contingent on the different levels of democratic age. Theoretically, the ties between democratic maturity and external efficacy in turnout explanation follow from aspects of political socialization process. We hypothesize that the higher the democratic age, the higher the positive effect of external efficacy on participation in elections. This supposition is tested through an empirical analysis based on survey data from the third module of the Comparative Study of Electoral Systems (CSES). In total, the dataset comprises 34,440 respondents nested in 27 countries. Multilevel logistic regression that includes cross-level interaction is employed to estimate the effects of the variables of interest on self-reported turnout.
\end{abstract}

\section{Keywords:}

voter turnout, democratic maturity, external efficacy, multilevel modeling, cross-level interaction

\section{Demokratische Reife, externe Wirksamkeit und Wahlbeteiligung}

\section{Zusammenfassung:}

Dieser Artikel analysiert die Bedeutung des Alters einer Demokratie für die Erklärung von Wahlbeteiligung. Er schlägt vor, dass die demokratische Reife die Wahrscheinlichkeit der Stimmangabe nicht nur direkt beeinflussen könnte, sondern zugleich auch als Verstärker der Effekte von Prädiktoren auf der Individual-Ebene. Aus der Bandbreite der Variablen, die für eine Erhöhung oder Verringerung der Wahrscheinlichkeit der Stimmabgabe verantwortlich sein könnten, hebt diese Studie hervor, dass das politische Responsivitätsgefühl (externe Wirksamkeit) vom Alter einer Demokratie abhängen könnte. Der Zusammenhang zwischen demokratischer Reife und externer Wirksamkeit für die Erklärung von Wahlbeteiligung lässt sich theoretisch aus Aspekten des politischen Sozialisationsprozesses herleiten. Unsere Hypothese ist, dass mit steigendem Demokratiealter auch die positiven Effekte externer Wirksamkeit auf die Wahlbeteiligung zunehmen. Diese Vermutung wird mittels einer empirischen Analyse getestet, die auf Survey-Daten aus dem dritten Modul der Comparative Study of Electoral Systems (CSES) zurückgreift. Das Daten-Set besteht aus insgesamt 34.440 Befragten in 27 Ländern. Es wird eine logistische Regression verwendet (Mehrebenen-Analyse inklusive Interaktions-Analyse), um die Wirkung der uns interessierenden Variablen auf die Wahlbeteiligung (nach den Angaben der Befragten) abzuschätzen.

\section{Schlüsselwörter:}

Wahlbeteiligung, demokratische Reife, externe Wirksamkeit, Mehrebenen-Modellierung, Mehrebenen-Interaktion

This article was supported by the Czech Science Foundation (Grant No. I4-29IIIS: Patterns and Trends in Social Mobility in the Czech Republic between 1990 and 20IO) and by a project of specific research at the Faculty of Social Studies of Masaryk University entitled "Contemporary Problems in Political Science Research" (code: MUNI/A/I342/2OI4).

The authors have declared that no competing interests exist. 


\section{Introduction}

In the past ten or fifteen years, there has been a growing discussion asserting that political participation is not the result of personal characteristics or political context, but that it is the result of interactions between both types of factors (e.g. Platt 2008: 392). Following this statement, a stream of papers that introduces possibilities for bridging macro- and micro-level predictors of voter turnout has emerged (Andiuza Perea 2002; Jusko/Shively 2005; Fieldhouse et al. 2007; Anderson 2007; Gallego 20IO; Rocha et al. 20IO; Quintelier et al. 20IO; Dalton/Anderson 20II; Kittilson/Anderson 20II; Singh 20II; Söderlund et al. 20II). This type of work has repeatedly shown that contextual factors may substantially enrich individual-level explanations for why people vote not only by the inclusion of their direct effects on voting propensity, but also by so-called contingent effects (see below; Brambor/Clark/Golder 2006).

Not surprisingly, there are still several context-level forces whose impacts have not been sufficiently examined. From an array of these overlooked factors, we have chosen for further investigation the nature of democracy, where citizens make a decision about whether to cast a ballot. The reason for this choice is simple. There is a "conventional" individual-level turnout explanation, which was developed and rather successfully utilized in long-established democracies, in particular, in the United States (Campbell et al. 1954; 1960; Verba et al. 1995; Rosenstone/Hansen 2003). However, there are also those democracies that have gone through the process of democratic transition only a few years ago. In these societies, living under authoritarian rule has shaped people's everyday experiences, and to a certain extent, such historical legacy may more or less affect the (different) functioning of conventional determinants of voter turnout (cf. Bernhagen/Marsh 2007; Kostadinova 2009). Hence, it would appear that some difference in the impact of the explanatory variables caused by democratic maturity might exist.

Accordingly, one might assume that there could be a contingent effect of democratic age, which should be manifested by the non-uniform size of the impact of some variables that explain probability of voting at the individual level. This study stresses that the effect of a sense of political efficacy (more precisely, its external dimension) should be moderated by the maturity of a democracy. Political efficacy is often described as a long-term attitude acquired in the process of political socialization, which is based on the feeling that ordinary people are capable of influencing the democratic process (see Campbell et al. 1954; Easton/Dennis 1967; Iyengar 1980; Pasek et al. 2008; cf. McPherson et al. 1977).

In established democracies, as we would expect, there are experienced agents of political socialization and the atmosphere is more favorable to values congruent with democracy. People learn to believe that their political en- gagement can foster change, and thus, those who are politically effective should vote much more than others. In contrast, many citizens in emerging democracies have been socialized into non-democratic values and they are hardly able to develop basic orientations and practices in those who are in their formative years (Sapiro 2004). Therefore, the impact of political efficacy on probability of voting in these countries should be small or none.

Simply put, the main objective of this study is to search for empirical support for the macro-micro interconnection between two factors that explain voter turnout, democratic age, and external efficacy, utilizing some important aspects of the political socialization process as a mechanism that might bridge the individual and contextual levels of the analysis. The paper addresses this issue by using multilevel models that include cross-level interaction. The empirical analysis below uses data from the third module of the Comparative Study of Electoral Systems. In total, 34,440 respondents from 27 countries are included.

\section{How democratic maturity matters}

It is often emphasized that well-designed democratic institutions are a necessary, but not sufficient condition for a vital democracy. For the smooth running of a political system, democratic citizens who lend support to a regime are also required (e.g. Easton 1957). Regarding the debates about the requirements of a stable democracy, Almond and Verba's seminal study entitled The Civic Culture can be considered one of the most influential works in this field of research (Almond/Verba 1963). The major conclusion of this study, namely that citizens' psychological orientations to the political institutions congruent with democratic principles are crucial for the durability and successful persistence of a democracy, sounds persuasive, and this paper does not attempt to challenge the idea that a political regime must be not only legal, but also legitimate for its maintenance.

At the same time, however, it is clear that "good" democratic citizens are made, not born (Gastil 200I). In a stable democracy, then, attitudes toward a political system (and its various parts) and toward the self in the system, jointly called political culture, must be inculcated by the various agents of a democratic political system. And it is noteworthy that the process of political socialization, in which the individuals develop basic orientations and practices for their future political life, is not identical in all countries. ${ }^{\mathrm{I}}$

I Political socialization can be defined as a training process mediated through socialization agents leading to the development of a political culture that may allow democratic institutions to 
In different contexts, socialization agents disseminate different messages about citizenship to those who are learning to contribute support to a regime (Sapiro 2004; Gimpel et al. 2003; Pacecho 2008).

Thus, while Almond and Verba's study (1963) has underlined that an adequate set of political orientations fosters democratic stability, there are other scholars who anticipate that the relationship between attitudinal variables and the viability of a democracy lies rather in the expectation that the long-term functioning of democratic institutions should, through various "promoters" of a democracy, gradually produce a democratic political culture (Barry 1978; Muller/Seligson 1994; Mishler/Rose 200I). As a logical consequence, one can assume that the relationship between civic orientations and democratic age might be reciprocal. In Eastonian terms, on the one hand, a political system needs support for its maintenance, but at the same time, it is capable to generate and accumulate a strong reserve of support (see Easton 1957).

The common denominator in both views on the direction of the relationship between civic values and democratic age resides in political socialization and the agents responsible for the success of this process. Reference to the forces from individuals' surroundings, such as family, peer groups, mass media, and schools, implies that there are different levels of the context in which people in their formative years acquire the norms and behavior supportive of a political regime.

However, the basic question concerns what level of context is the most important for the success of political socialization. When forming an opinion on this issue, it is important to point out that all of these forces find the basis for their influence at the level of a political system. To be more concrete, family members and peers, as well as media workers, are educated in schools. And since education is provided and funded by the public sector to a large extent, states have the main say in what the pupils will learn and what kind of teachers will give the lessons. ${ }^{2}$ Hence, the nature of political socialization that may lead to the absorption of "proper" political attitudes and practices should depend primarily on what is going on in the national political arena. Due to the pivotal role of schooling, the lower levels of the context in which individuals are nested (groups, households etc.) are substantially affected by the national level (cf. Gimpel et al. 2003; Pacheco 2008; Almond/Verba 1963).3

function (cf. Hyman 1959; Easton/Dennis 1967; Sigel 1970; Shapiro 2004; Franklin 2004; Jennings 2007; see also Janák/Klobucký 2OI4a; 2OI4b).

2 For justifying the crucial role of schooling in the process of political socialization, see e.g. Gastil (200I) or Pasek et al. (2008).

3 We admit that this argument may be controversial in several aspects. Above all, there are studies that emphasize the lower levels of context pivotal for political socialization. Further, for some other authors, the process of political socialization is rooted not only in
One might reasonably believe that the most successful transmission of democratic norms will be typical for political regimes in which the vast majority of citizens was socialized in a democratic milieu. When a democracy is genuinely old, socialization agents are highly experienced and a democratic polity is for them "the only game in town." On the other hand, in emerging democracies, some proportion of these agents has grown up in an atmosphere of non-democratic values and the chance that they will be successful in the political socialization process is not as high as in long-established democracies (see Shapiro 2004).

Since there are certain arguments asserting that the degree of the successful instilling of proper (I) civic values and (2) behavior might depend on democratic maturity, we expect that there should be two distinct influences of democratic age that can be described as its direct and contingent effects. When focusing on the first, democratic age may directly affect the propensity of voting. Given the experience of socialization agents in mature democracies, it is reasonable to assume that voting in these countries will be perceived as a norm, and people will exert great social pressure for participation in elections. Therefore, the higher the democratic age, the higher the probability of voting should be.

To this, we must add that the association between the character of a democracy and the percentage of people that vote cannot be regarded as something novel (see Norris 2002; Blais/Dobrzynska 1998; Endersby/Krieckhaus 2008; Söderlund et al. 20II). In previous research, however, the direct impact of democratic maturity on voter turnout has often been reduced to a description of turnout differences between so-called "old" and "new" democracies (e.g. Bernhagen/Marsh 2007; Karp/Banducci 2007; Nový 2013; see also Franklin 2004). At the same time, the entrance to the club of old democracies has been usually guaranteed after twenty years of continuous functioning of the democratic process in a given country (Nohlen 2002; Karp/Banducci 2007).

For us, the old/new dichotomy appears a little outmoded. To demonstrate its disappointing nature, we turn our attention to three southern European, post-authoritarian countries - Spain, Portugal, and Greece. Despite having undergone the process of democratic transition in the late 1970s, these countries can be considered rightful members of the group of old democracies, side by side with countries such as the United States, in which democracy was established more than two hundred years ago. At present, post-communist countries have also fulfilled the condition of being democratic for more than twenty years, and therefore, they have become older, albeit the politics in these units diametrically differs

the formal (manifest) influence of socialization agents, but also in the unintentional transmission of values (for example, what the individual hears in the family in ordinary talk, etc.). 
from that in the traditional core of Western democracies (Rose 2009; Pacek et al. 2009; Pop-Eleches/Tucker 20II; 20I4; Kostadinova 2003).

In this paper, we attempt to overcome this difficulty in the way that democratic maturity is perceived by treating it as a continuous variable indicating how many years of uninterrupted functioning of democratic rule has passed through the election under analysis. We introduce the operationalization of this variable in more detail in the next section.

As noted above, aside from its direct impact on voter turnout, democratic maturity may also have a contingent effect. This study anticipates that the age of a democracy may function as an "amplifier" of the impact of some individual-level variables on voting propensity. We hypothesize that in the first place, the moderating influence of democratic age should relate to a sense of political efficacy, or more precisely, to an external dimension of this sense (see Hadjar/Beck 20IO).

A sense of external efficacy has been chosen because it is often perceived as developed during the formative years in which the openness to stimuli from political socialization agents is the highest (Easton/Dennis I967; Pasek et al. 2008; cf. McPherson et al. 1977). In addition, some authors do not hesitate to place external efficacy among the indicators of support for a political system (e.g. Iyengar 1980; Norris et al. 2005), and thus, it appears very closely related to the issue of how to provide democratic stability.

Generally speaking, political efficacy refers to "the feeling that individual political action does have, or can have, an impact upon the political process, i.e., that it is worth while to perform one's civic duties. It is the feeling that political and social change is possible, and that the individual citizen can play a part in bringing about this change." (Campbell et al. 1954: 187) But as indicated previously, political efficacy does not seem to be a unidimensional concept. It is usually considered to have two components, external and internal (Balch 1974; Converse 1972). While internal efficacy relates to beliefs about an individual's competence to understand politics and participate effectively in political life, external efficacy involves beliefs about how responsive the government is to citizens' needs and demands.

The direct impact of a sense of external efficacy on participation in elections has been commonly studied in the literature on political behavior (Campbell et al. 1954; Campbell et al. 1960; Verba/Nie 1972; Abramson/Aldrich 1982; Pollock 1983; Verba et al. 1995; Rosenstone/Hansen 2003; Norris 2004 etc.). The association between external efficacy and probability of voting is expected to be positive. This is because citizens with a greater sense of efficacy may think, despite the fact that electorates usually comprise millions of people, that their political action has a substantive effect on political outcomes, and thus, they are more likely to turn out than those with a lower sense of efficacy.

On the other hand, the contingent effect of democratic age on external efficacy, which may cause the size of the effect of efficacy on voting propensity to be different across countries, has largely not been discussed by scholars. Considering the arguments raised above, we hypothesize that increasing democratic maturity will strengthen the positive impact of external efficacy on the probability of casting a ballot. In other words, due to differences in the nature of political socialization, the highly positive and significant effect of external efficacy should be typical of long-established democracies. ${ }^{4}$ In contrast, in newer democracies, the factors related to an authoritarian legacy, in particular, the lack of experienced socialization agents, might decrease the relevance of a "conventional" explanation of electoral participation that includes a sense of external efficacy (cf. Kostadinova 2009). Therefore, the impact of external efficacy should not be statistically significant in countries where the democracy is just developing.

\section{Micro- and macro-level controls}

The literature on political participation refers to an extensive set of factors that can affect voter turnout (see Smets/van Ham 2013; Geys 2006; Leighley/Nagler 1992; Bühlmann/Freitag 2006). Here we address the impact of a sense of external efficacy and democratic age, stressing that these two variables may influence individuallevel turnout not only separately, but also jointly. In the models, however, it is necessary to control for the effects of some other micro- and macro-level characteristics perceived to be important for the decision of whether to vote. ${ }^{5}$ At the individual level, the so-called Civic Voluntarism Model (CVM) may represent a useful theoretical framework for explaining electoral participation (Verba et al. 1995). The CVM posits that people are politically active because (I) they can, (2) they want to, and/or (3) someone has asked them (for more detail, see also Norris

4 Many seminal studies that have elaborated the most influential theoretical models of political participation (e.g. the Civic Voluntarism Model) usually reflect the situation in consolidated democratic regimes such as the United States (Verba et al. 1995; Rosenstone/Hansen 2003 etc.). But why should these models function identically in different contexts?

5 It is necessary to add that we do not have enough space to describe all control variables in detail. The impact of some variables discussed in this section, in particular those from the macro level, is often perceived to be ambiguous (see e.g. Norris 2002; Blais/Dobrzynska 1998; Geys 2006). At the same time, we must stress that our control variables are not able to exhaust the field of the research to a maximum extent, and many significant relationships may remain omitted. (At the individual level, we are limited by the content of the CSES surveys; at the contextual level, we are forced to minimize the number of explanatory variables because of the small number of the contexts.) 
2002; Dalton 2014). In turn, three main groups of factors influence the decision to participate: personal resources (the predispositions determined by position in social structure), subjective motivation (i.e. political attitudes), and mobilization (the degree of social integration).

First, participation in politics places demands on people's scarce resources. Voting has a price, and those with a greater capacity to bear it are more likely to visit a polling place. In this study, age and education are included as explanatory variables. Age refers to the amount of experience of an individual. Older citizens should vote in higher proportions because they are established in their communities and they usually show a greater familiarity with the electoral process and public policy problems. Education may be regarded as a measure of cognitive skills that make voting easier. Schooling increases one's capacity for understanding and working with the complex and abstract issues common in politics (Wolfinger/Rosenstone 1980; Norris 2002).

However, although some people have leisure time, skills, and other resources, they simply do not want to participate. This is why the second component of the CVM highlights the necessity of subjective motivation to vote. It concerns the impact of various political attitudes on the probability of voting. Besides the sense of external efficacy discussed above, the paper examines the influence of three additional psychological orientations: party identification, satisfaction with a democracy, and campaign involvement. Party identification can be described as the long-term affective attachment to a certain political party acquired at an early age (e.g. Campbell et al. 1960; Crewe 1976; Heath 2007). Those who are emotionally close to some political party have a strong incentive to support it on Election Day, and therefore, they are more likely to vote than people lacking identification. Satisfaction with a democracy concerns the subjective evaluation of how well the political system works. People who are discontent with a democracy should abstain more often than their satisfied counterparts. We expect such an impact because dissatisfied citizens may be less prone to express loyalty to the political regime through conventional forms of political action such as voting (Grönlund/Satälä 2007; cf. Hadjar/ Beck 20IO). We also control for the impact of campaign involvement, anticipating that citizens who followed an election campaign closely are more likely to vote than those who did not (see Campbell et al. 1960).

The last pillar of the CVM provides an additional layer of complexity by employing the degree of social integration as a factor that may affect the probability of voting. People who are mobilized by various political agents (in particular, political parties and candidates) and/or who are connected to some groups, organizations, and social networks (union members, churches, etc.) are more stimulated to be politically active. The analysis be- low focuses on the impact of two variables, i.e. marital status and union membership. Marriage may be beneficial for turnout because a spouse can act as another mobilization agent who discusses politics in the household, provides information about elections, and motivates his or her wife or husband to take part at the polls. In a similar fashion, union membership exposes people who are attached to employee associations to various political stimuli (through meetings, discussions, special events, etc.) that increase the probability of participation in elections (Rosenstone/Hansen 2003).

In addition to the CVM, our models also contain a variable that reports whether a respondent has voted in previous elections. This variable can be regarded as the factor that measures so-called habitual voting. For many people, participation in elections becomes a habit that is repeated as a response to a certain stimulus - i.e. the coming of Election Day - on a regular basis (e.g. Green/ Shachar 2000; Aldrich et al. 20II). Simply put, someone who once voted is more prone to do it again.

As noted earlier, at the contextual level, democratic age is central to our interest. However, there are some other macro-level forces that may affect voter turnout. In this study, we use five context-level controls: electoral salience, compulsory voting, closeness of election (i.e. margin of victory), proportional electoral system, and the logarithm of GDP per capita. The first four reflect the influence of political institutions. In brief, electoral salience indicates how important a given election is for the future of a country, or in other words, what is at stake. Not surprisingly, in a parliamentary regime, the most salient are parliamentary elections, while in presidential regimes, presidential elections play a crucial role. It is thus expected that the more decisive the elections are, the higher the turnout should be (Reif/Schmitt I980; Blais/Dobrzynska 1998, etc.). Compulsory voting may also cause a significant increase in the level of voter turnout. If there is the threat to be fined for abstention, the cost of non-voting becomes higher than the cost of voting, and therefore, people have a strong incentive to go to the polls (Panagopoulos 2008; Birch 2009).

Closeness of elections shows how competitive a given electoral race is. It is usually measured as the margin of victory, i.e. the difference in vote shares between the political party that occupies first place in terms of the number of votes and the second strongest party. If every single vote may cause a change in who wins the race and the winner is uncertain until the last moment, the probability of casting a decisive vote is relatively high; hence, people vote more frequently than in the situation when there is a substantial margin between the first and second party (Matsusaka 1993; cf. Cox/Munger 1989). Finally, it is often highlighted that the electoral formula may influence the willingness to vote. The conventional wisdom is that proportional representation (PR) systems 
generate higher rates of voter participation than majoritarian (and other) systems (see Norris 2002; Blais/ Dobrzynska 1998). This is because under proportional systems, most parties have a chance to win at least one seat; therefore, citizens - in particular those who prefer smaller parties - do not have to be fearful that their vote will be wasted. Thus, the opportunity to vote sincerely is the main element that may encourage people to turn out (Jackman/Miller 2004; Ladner/Milner 1999).

The final context-level variable gauges the level of socioeconomic development in a country. Citizens in more affluent societies usually enjoy more leisure time, have relatively easy access to education and various sources of information, engage in non-manual and well-paid work, and live in cities or suburbs. A higher living standard enables people to participate in politics, and therefore, turnout should be higher in advanced societies (e.g. Powell 1982). However, some authors have pointed out that the relationship between socioeconomic development and turnout rates is not linear. While the level of development is theoretically unconstrained, voter turnout is limited by an upper bound, i.e. I00\%. In light of this difficulty, it appears to be more appropriate to model the relationship by using a logarithmic function(Norris 2002).

\section{Data and methods}

We restrict the analysis to countries included in the third module of the CSES for which all the variables used in the models below (i.e. variables of interest and controls) are available. Given this reduction of the original dataset, 34,440 respondents from 27 countries are utilized for modeling the effects of independent variables on voting. ${ }^{6}$ The dataset is characterized by a hierarchical structure: at the first level (micro level), individuals are settled. These individuals are nested in the countries that constitute the second level (macro level) of the analysis. Due to this structure, multilevel modelling with logit link function (the response is binary) is employed to estimate the impact of the predictors of voter turn-

6 Elections included in the analysis (number of respondents in parenthesis) are Australia 2007 (I873), Brazil 2010 (2000), Czech Republic 2010 (I857), Germany 2009 (2095), Denmark 2007 (I442), Estonia 2OII (IOOO), Finland 20II (I298), France 2007 (2000), Greece 2009 (IO22), Croatia 2007 (IOO4), Israel 2006 (I2O0), Japan 2007 (1373), South Korea 2008 (I000), Mexico 2009 (2400), Netherlands 2010 (2153), Norway 2009 (I782), New Zealand 2008 (II49), Poland 2007 (I817), Slovakia 2010 (I203), Slovenia 2008 (IO55), Sweden 2006 (I547), Romania 2009 (I403), Canada 2008 (4495), Peru 2011 (1570), Philippines 2010 (I200), Turkey 20II (IIO9), and the United States 2008 (2IO2). It covers 44,I49 respondents in total. However, because of missing values, only 34,440 respondents are included in the empirical analysis below. It is also worth noting that in several countries (Brazil, Germany, Iceland, Mexico, Poland, and the Czech Republic), the third module of the CSES was administered twice. This analysis takes into account only the newer survey. out (Gelman/Hill 2007; Hox 20IO; Rabe-Hesketh/Skrondal 20I2). The major advantage of multilevel models is their ability to combine characteristics from the micro level with those from the macro level, assuming that the variation in the dependent variable comprises two parts, within- and between-group components.

The dependent variable, participation in an election, is observed at the first level. In our dataset, it gauges selfreported turnout mainly in parliamentary elections held from 2006 to $2011 .{ }^{7}$ When comparing the aggregate levels of electoral participation as declared by the respondents in the survey with the actual turnout rates from the database of International IDEA ${ }^{8}$ (see Appendix A), it is notable that the results of the analysis portray a rather rough picture of how the explanatory variables actually influence electoral participation (see Sigelman I982). ${ }^{9}$

Our research strategy is based on the sequential development of a multilevel model. We start with the socalled null model, i.e. a model in which no independent variables are included, to demonstrate the ratio of within- and between-group components of variance in the dependent variable. In the second step, we add the set of explanatory variables from the individual level. For us, a sense of external efficacy is the pivotal factor at the micro level. Unfortunately, it is necessary to point out that the concept of political efficacy is burdened by the voluminous discussion of how to measure it (e.g. Craig/ Maggiotto 1982; Craig/Niemi/Silver 1990; Acock/Clarke 1990). Since there is no consensus about the objective measurement of efficacy, of course, this work may be easily criticized for its operationalization and doubtful validity. ${ }^{10}$ Like Karp and Banducci (2008) or Norris

7 There are several exceptions: In Romania and in the Philippines, presidential elections are taken into consideration. In Brazil, Peru, and the United States, the survey reflects the intersection between parliamentary and presidential elections. The different importance of elections is reflected in the models through the variable called electoral salience.

8 The International Institute for Democracy and Electoral Assistance likely administers the most extensive global database of turnout rates after World War II.

9 We attempted to overcome this difficulty by weighting the cases according to actual turnout. Given the overestimation of selfreported turnout (see Appendix A), non-voters received a weight higher than I, while voters' weight was designed to be lower than I (the exact number for each country followed from the degree of overestimation of self-reported turnout, i.e. from the proportion between actual and self-reported turnout). Since the statistical package (Stata II, xtmelogit command) employed for the analysis does not allow data weighting in multilevel models, weights were applied on the series of fixed effects models (i.e. models that include, in addition to the set of individual and contextual-level predictors, dummy variables for particular countries, and thus allow the intercept to vary across contexts; see Brooks 2008: 493-494). The outcome of fixed effects models was nearly the same as in multilevel models without weighting. For this reason, in the empirical section, only multilevel models are introduced. The fixed effects models are presented in Appendix C.

Io Apparently, the most common measure of a sense of political efficacy is the four-item agree-disagree scale that includes following statements: (I) Sometimes politics and government seem so 
Table 1. Descriptive statistics

\begin{tabular}{|c|c|c|c|c|c|}
\hline Variable & Type & Mean & Std. Dev. & Min & Max \\
\hline \multicolumn{6}{|l|}{ Individual level } \\
\hline Vote & DUM $(1=$ voted $)$ & .87 & .34 & 0 & 1 \\
\hline External efficacy & CON & 3.95 & 1.20 & 1 & 5 \\
\hline Age & CON & 47.25 & 16.99 & 20 & 90 \\
\hline Education & DUM (1 = tertiary) & .27 & .44 & 0 & 1 \\
\hline Party identification & DUM (1 = identified) & .52 & .50 & 0 & 1 \\
\hline Satisfaction with democracy & DUM (1 = satisfied) & .60 & .49 & 0 & 1 \\
\hline Campaign involvement & DUM (1 = followed $)$ & .57 & .49 & 0 & 1 \\
\hline Marital status & DUM (1 = married) & .64 & .48 & 0 & 1 \\
\hline Union membership & DUM (1 = member) & .17 & .37 & 0 & 1 \\
\hline Previous election & DUM (1 = voted $)$ & .83 & .38 & 0 & 1 \\
\hline \multicolumn{6}{|l|}{ Contextual level } \\
\hline Democratic maturity & $\operatorname{CON}(\ln )$ & 3.62 & .90 & 1.95 & 5.34 \\
\hline Electoral salience & CON (2 = highest $)$ & 1.70 & .58 & 0 & 2 \\
\hline Compulsory voting & DUM (1 = yes) & .17 & .37 & 0 & 1 \\
\hline Closeness of election & CON & 7.96 & 5.84 & .7 & 24 \\
\hline PR & DUM $(1=P R)$ & .56 & .50 & 0 & 1 \\
\hline GDP per capita & $\operatorname{CON}(\ln )$ & 10.04 & .83 & 7.67 & 11.26 \\
\hline
\end{tabular}

Data sources: CSES III, Polity IV. Project, Parties and Elections in Europe, and Adam Carr's Election Archive. N = 34,440 (nested in 27 countries). CON - continuous; DUM - dummy variable.

(2004), we associate a sense of external efficacy with the CSES item: "Some people say that no matter who people vote for, it won't make any difference to what happens. Others say that who people vote for can make a big difference to what happens. Using the scale on this card (where one means that voting won't make any difference to what happens and five means that voting can make a big difference), where would you place yourself?"

For Karp and Banducci (2008: 319), the question asking respondents to evaluate the meaningfulness of voting is the most direct measure of evaluations of efficacy of the vote available. These authors also stress that it is strongly associated with other measures of external efficacy, and "therefore, there is clear evidence that the CSES item measures an aspect of external efficacy." (ibid: footnote no. 38).

Aside from our key individual-level variable, the model is enriched by several measures of personal re-

complicated that a person like me can't really understand what's going on; (2) Voting is the only way that people like me can have a say about how the government runs things; (3) I don't think public officials care much what people like me think; and (4) People like me don't have any say about what the government does (e.g. McPherson et al. 1977). The first two items are usually perceived as measures of internal efficacy, and the latter two items should indicate one's external efficacy (Balch I974; Converse 1972). sources, motivation, and mobilization (Verba et al. 1995). Personal resources are represented by basic socio-demographic variables, i.e. age and education. ${ }^{\text {II }}$ From an array of motivational characteristics, in addition to external efficacy, we control for party identification, satisfaction with democracy and campaign involvement. The aspects of mobilization for participation are included through marital status and union membership. Because voting is often perceived as a habit, participation in a previous election is put into the models as an explanatory variable.

Subsequently, we allow the effect of external efficacy to vary randomly across countries. Since the analysis below documents that in some countries, a sense of external efficacy does not have a significant impact on selfreported turnout, while in others it does, it is legitimate to search for context-level forces that might be responsible for the variation in the size of this effect. In the previous paragraphs, we have attempted to describe that in the first place, democratic maturity might moderate the effect of external efficacy. This variable is derived from the Polity IV. Project. The value for each country cor-

II In our models, gender was not significant. Household income was not included due to a large number of missing values. 
responds with the number of years the democracy has functioned without any interruption. In this study, we associate the starting point of a democracy with the moment a particular state has reached or exceeded a Polity Score of $+7 .^{12}$ Such a threshold was chosen based on the work of Jaggers and Gurr (1995: 474), which asserts that political regimes with scores of +7 to $+\mathrm{IO}$ are "coherent" democracies. Before the analysis, however, it was necessary to transform this variable. We symmetrized its distribution using logarithmic transformation.

Naturally, we also make an effort to include contextlevel controls into our hierarchical model. In addition to democratic maturity, the effects of electoral salience, compulsory voting, closeness of election (i.e. victory margin), proportional electoral system and the logarithm of GDP per capita are added. ${ }^{13} \mathrm{~A}$ detailed description of all the variables utilized in the empirical analysis is available in Appendix B. Descriptive statistics of these characteristics are introduced in Table I.

The conclusion regarding whether the impact of external efficacy is contingent on democratic maturity is based on an assessment of the interaction between both variables of interest. The joint effect of these variables is included in the model in the last step of the analysis. The interaction effect is calculated as a product of the variables that should theoretically influence each other (Kam/Franzese 2007). The discussion below, in particular, elaborates whether the contingent effect of democratic age is sufficiently strong enough to be significant.

\section{Empirical analysis}

The following paragraphs reflect the outcome of multilevel models in which self-reported turnout is regarded as a response. In this section, we present five models. We start with the empty or null model (without any explanatory variables) and move to the more complicated random-intercept random-slope model that includes cross-level interaction (see Table 2). From the null model (Model o), the justification for using hierarchical models can be derived. Given the value of the intraclass correlation coefficient (ICC), nearly 24 percent of the variation in individual-level self-reported turnout can be attributed to forces at the contextual level, and therefore,

I2 The Polity score is a measure enumerated through the merging of two composite measures, the indicators of democracy and autocracy. Both of these are gauged on an eleven-point scale (o to IO). The final score is computed by the subtraction of the autocracy score from the democracy score. The value + IO depicts the most democratic regime and -Io the most autocratic regime (Marshall et al. 20II; Gurr I974).

I3 Some other context-level factors, e.g. the human development index or the effective number of legislative parties, were not significant in any of the models, and therefore, they were excluded from the analysis. single-level logistic regression does not appear to be the proper statistical technique in this case.

When individual-level covariates are added (Model I), noticeable changes in values that characterize how the model fits the data, log likelihood (LL) and Bayesian information criterion (BIC), are evident. This finding implies that micro-level factors make the model much more accurate compared to the null model. As can be seen, the effect of external efficacy on declared turnout is positive and highly significant. Those who feel more strongly that their vote can make a big difference in what happens appear to be thus more likely to vote than less efficacious people.

In addition to external efficacy, the effects of all individual-level controls with the exception of age ${ }^{\mathrm{I} 4}$ are also statistically significant. Therefore, there is empirical evidence that voting should be more widespread among the highly educated, those who feel close to any political party, those who are satisfied with the functioning of a democracy, and those who have followed the preelection campaign closely. The probability of visiting a polling place seems to be also higher when one is married and/or declares membership in a union. Finally, the outcome of Model I indicates that voting may be perceived to be a habit, because those who reported participation in a previous election should have nearly five times higher odds of casting a ballot compared to those who did not. ${ }^{15}$

In light of the preceding sections of this paper, we could suppose that the impact of external efficacy will not be equal in all contexts. According to this expectation, the variation in the effect of external efficacy has been allowed in Model 2. An LR test (not reported in Table 2) has confirmed that the addition of such random effect has brought a significant improvement of the mod-

I4 Although not significant at the o.Io level, the effect of age was not excluded from the analysis. The reason is twofold. First, in multilevel models, it was very close to being significant at the o.Io level. Second, in fixed effects models (see Appendix C), which can be perceived as a "pre-test" of our hypothesis, the effect of age was significant.

I5 Since the interpretation of $\beta$-coefficients is not completely readerfriendly, odds ratios are often used for a description of the results. Odds ratios are calculated as $\exp (\beta)$. The odds ratios higher than $\mathrm{I}$ denote a positive association between independent and dependent variables. Nevertheless, due to varying intercept, in multilevel models, the interpretation must be cautious. For example, let us focus on the $\beta$-coefficient near previous election in Model I. The $\beta$-coefficient $\left(\beta_{\mathrm{PRE}}=\mathrm{I} .6 \mathrm{O} 2\right)$ implies that its odds ratio will be $\mathrm{OR}_{\mathrm{PRE}}=$ $\exp (\mathrm{I} .602)=4.963$. Given this odds ratio, we can say that for citizens who are situated in the same country (i.e. holding random intercept constant), it is expected that odds of voting for those who cast a ballot in previous election are nearly five times higher compared to those who did not. In addition, we should also reflect that the model fit is not perfect at all. Therefore, we prefer not to interpret exact numbers of the coefficients in this section. A detailed description of the effect of previous election should serve as an instruction of how these coefficients may be interpreted (when the model fit is almost perfect). 


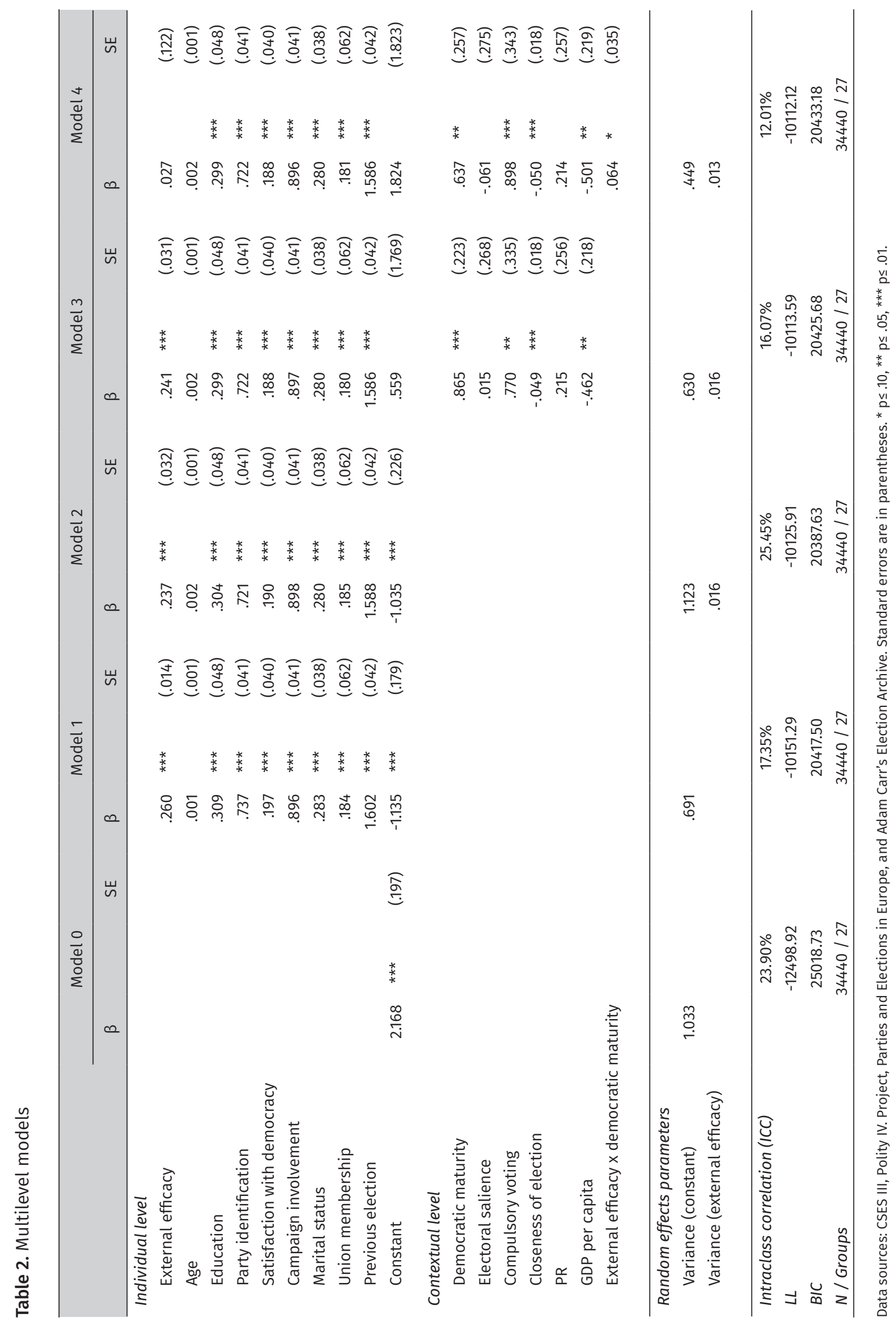


Figure 1. The effect of external efficacy on self-reported turnout by country

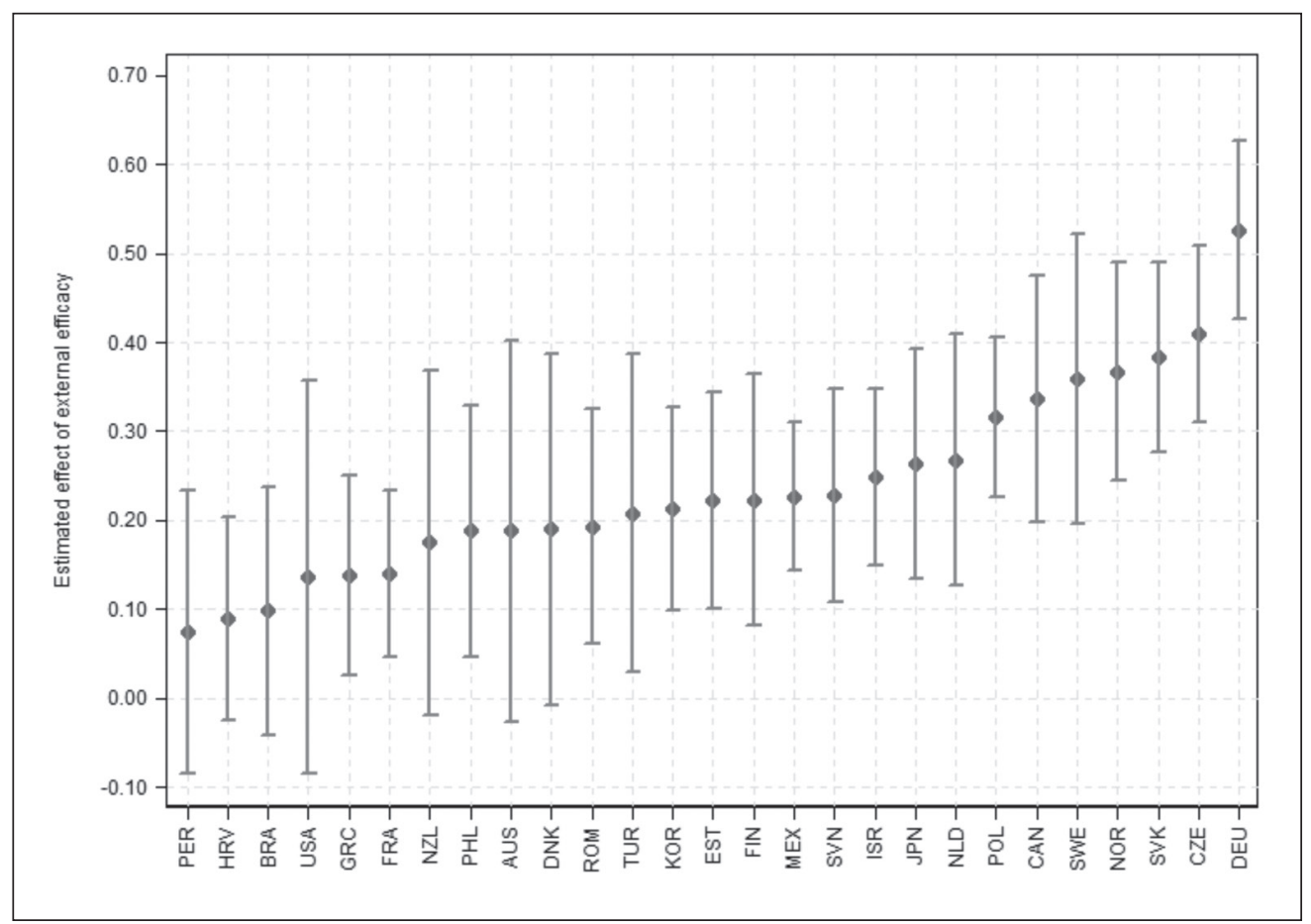

Data source: CSES III. Aside from the estimated effect of external efficacy, the $95 \%$ confidence interval is displayed.

el. ${ }^{16}$ Thus, it appears that the influence of one's efficacy on self-reported turnout actually varies across countries and the fixed effect $\left(\beta_{\mathrm{EFF}}=.237\right.$ in Model 2) can be regarded only as an average estimated impact that does not give complete information of how external efficacy matters. When considering the variance in its random effect $\left(\sigma_{\mathrm{EFF}}^{2}=.016\right)$, we can state that the size of estimated effect of external efficacy fluctuates roughly in the range of $.237 \pm .252$, i.e. from -.015 to $.489 .^{17}$ Thus, there are many

I6 Since we are not able to assess the significance of the random effect of external efficacy directly from Model 2 (as can be seen, there are no asterisks near the random effect), we must use some alternative test - in our case, the LR test was chosen - to evaluate whether this effect improves the model to the extent that it is adequate to include it. The LR test is based on the comparison of the deviances (calculated as -2LL) of two multilevel models where the first (less parsimonious) model enriches the second (more parsimonious) by one or more parameters. The difference in deviances is confronted with the criticalvalue of the chi-square distribution with the number of degrees of freedom corresponding with the number of extra parameters. In our analysis, thus, Models I and 2 are compared. The difference in their deviances is 50.76. Since two extra parameters were added (the variance of the random effect of external efficacy and the covariance of random intercept and random slope that is not reported in Table 2), the value is compared with the critical value of the chi-square distribution with 2 degrees of freedom. At the 5 percent significance level, its critical value is 5.99. Since the difference in deviances exceeds the critical value of the chi-square distribution, it can be concluded that the random effect of external efficacy has improved the model significantly.

I7 As noted above, the variance in the random effect of external efficacy was estimated in Model $2\left(\sigma_{\mathrm{EFF}}^{2}=.016\right)$. Accordingly, its standard deviation can be easily calculated $\left(\sigma_{\mathrm{EFF}}=. \mathrm{I} 26\right)$. We assume that the effect varies randomly across countries, and hence, it should be countries where the effect should be positive, but there are also some contexts characterized by no association between external efficacy and declared turnout.

We are also able to depict graphically how the effect of external efficacy varies across countries. As documented through the approximate calculation of the effect fluctuation using the basic knowledge on normal distribution, in some countries, the estimated effect of external efficacy tends to be highly positive, while in others it is not significant. Figure I shows the effects of external efficacy for particular countries. In seven of twenty-seven countries (Peru, Croatia, Brazil, United States, New Zealand, Australia, and Denmark), the 95 percent confidence interval contains null, which signifies that external efficacy has no or only minimal impact on voting. The remaining twenty contexts show a positive association between external efficacy and self-reported turnout, which, based on the theory, is commonly expected. The highest impact of external efficacy is estimated in Central European countries (Germany, Czech Republic, and Slovakia) and northern Europe (Norway and Sweden).

We must admit that, at first glance, it appears that the countries that show the lowest as well as the highest impact of external efficacy do not resemble each other

normally distributed. In the normal distribution, about 95 percent of the values lie within two standard deviations of the mean $\left(2 \sigma_{\mathrm{EFF}}\right.$ $=2 \times .126=.252)$. That is why the effect of external efficacy across countries was estimated using the interval .237 \pm .252 . 
according to their levels of democratic maturity. The first group of contexts, i.e. those with no impact of external efficacy on the decision whether to vote, includes states in which democracy is very well established - for instance, democratic rule has persisted for more than Ioo years in the United States, New Zealand, and Australia - alongside countries that have experienced democratic transition only a few years ago (Peru and Croatia). In the second category of countries, i.e. the states in which external efficacy should influence voting most significantly, high variation in democratic age also occurs. To demonstrate these differences, we can take Sweden, which has been considered a democratic system for almost ninety years, and compare it with such countries as the Czech Republic or Slovakia in which democracy has begun to develop just after 1989. Notwithstanding, in the last two stages of the analysis, we strive to ascribe cross-national variation in the effect of external efficacy on democratic age.

Before that, however, one might speculate what aspects of the context can stay beyond the fact that in the first group of countries, efficacious people vote roughly to the same degree as those who do not feel external efficacy, while in the remainder, such people participate more in elections. Except for Croatia and the United States, the group of countries that shows no significant impact of external efficacy on voting is characterized by very high turnout rates (see Appendix A). In addition, Australia, Brazil, and Peru have laws for compulsory voting. Because it is a mathematical fact that when turnout tends toward 100\%, people of all kinds vote in the same proportions (see Tingsten 1937; Gallego 2015), we could imagine that to a certain extent, the non-significant effect of a sense of external efficacy is caused by high levels of voter turnout. ${ }^{18}$

In contrast, the countries, in which external efficacy matters most for the decision regarding whether to vote, differ considerably in their levels of actual turnout (from $82 \%$ in Sweden to $59 \%$ in Slovakia), and hence, the speculative explanation presented above cannot be applied. But these states share another characteristic relevant for political behavior - electoral systems that generate relatively proportional outcomes. To this, we must add that electoral system and external efficacy are interconnected concepts: since fewer votes are wasted under PR (compared to majoritarian) systems, the use of this electoral formula may contribute to the belief that every

I8 When thinking about the remaining two countries, other explanations may be suggested. In the United States, for example, the non-significant effect of external efficacy on self-reported turnout might be caused by large population size, which decreases the motivation of efficacious people to go to the polls. In Croatia, an authoritarian legacy (which persisted until Franjo Tuđman's death in 1999), together with the war of independence, may represent two main reasons why efficacious people voted to the same degree as the inefficacious. single vote is important for a political contest (e.g. Geys 2006; Bühlmann/Freitag 2006). In these contexts, thus, efficacious citizens may have a strong incentive to cast a ballot, which results in greater gaps in turnout rates between efficacious and inefficacious people.

So far, the role of context in the models has been perceived as rather indefinite, expressed by random intercept and random slope (and therefore, some speculative explanations have been discussed). ${ }^{19}$ Through the inclusion of context-level factors into the model, Model 3 attempts to specify the impact of forces from the contextual level that might be responsible for the variation in random effects. In this model, the direct effects of six variables are added. For us, however, the key contextual variable is democratic maturity. Its effect on self-reported turnout is positive and highly significant $\left(\beta_{\text {MAT }}=.865\right)$. This finding implies that citizens who live in long-established democracies are more prone to vote. From context-level controls added into the model, we can note that the voting decision may depend to a certain extent on factors such as compulsory voting, victory margin, and a state's economic performance. ${ }^{20}$ The newly added factors, not surprisingly, are responsible for a substantial decrease in the variance in the constant (it has dropped from I.I23 to .630).

We wish to emphasize that this study primarily has sought to assess the contingent effect of context, or more precisely, democratic maturity. Although Figure I has not fully demonstrated that the variation in the effect of external efficacy might be driven by democratic age (see above), we have added a cross-level interaction term linking external efficacy to democratic maturity into the model. The outcome of Model 4, which is the least parsimonious, signifies that the impact of external efficacy can be truly contingent upon the age of the regime. Although significant only at the .Io level, the estimate of the interaction term $\left(\beta_{\mathrm{EFF} \times \mathrm{MAT}}=.064\right)$ provides support for our initial expectation (i.e. the higher the democratic maturity, the higher the positive effect of external efficacy on propensity to vote).

Let us interpret this interaction in detail. At the lowest level of democratic maturity, the effect of external

I9 While the random intercept indicates that due to various aspects of the contexts (i.e. context-level variables), the probability of voting in some countries is higher than in others, random slope is used to demonstrate that due to context-level forces, the effect of individual-level variables on propensity to vote is not equal across countries. But the previous models do not specify these contextlevel forces at all. When appropriate contextual variables are added, the variance in the effect of external efficacy should be decreased, because the indefinite role of the context acquires "the true face." The inclusion of contextual variables should also reduce the variance in the constant, which relates to the direct impact of the context on voting.

20 In the fixed effects models, the impact of electoral salience and proportional electoral system was also significant (see Appendix C), and therefore, both context-level controls have been included in the multilevel models. 
Figure 2. The relationship between democratic maturity and country effects of external efficacy on self-reported turnout

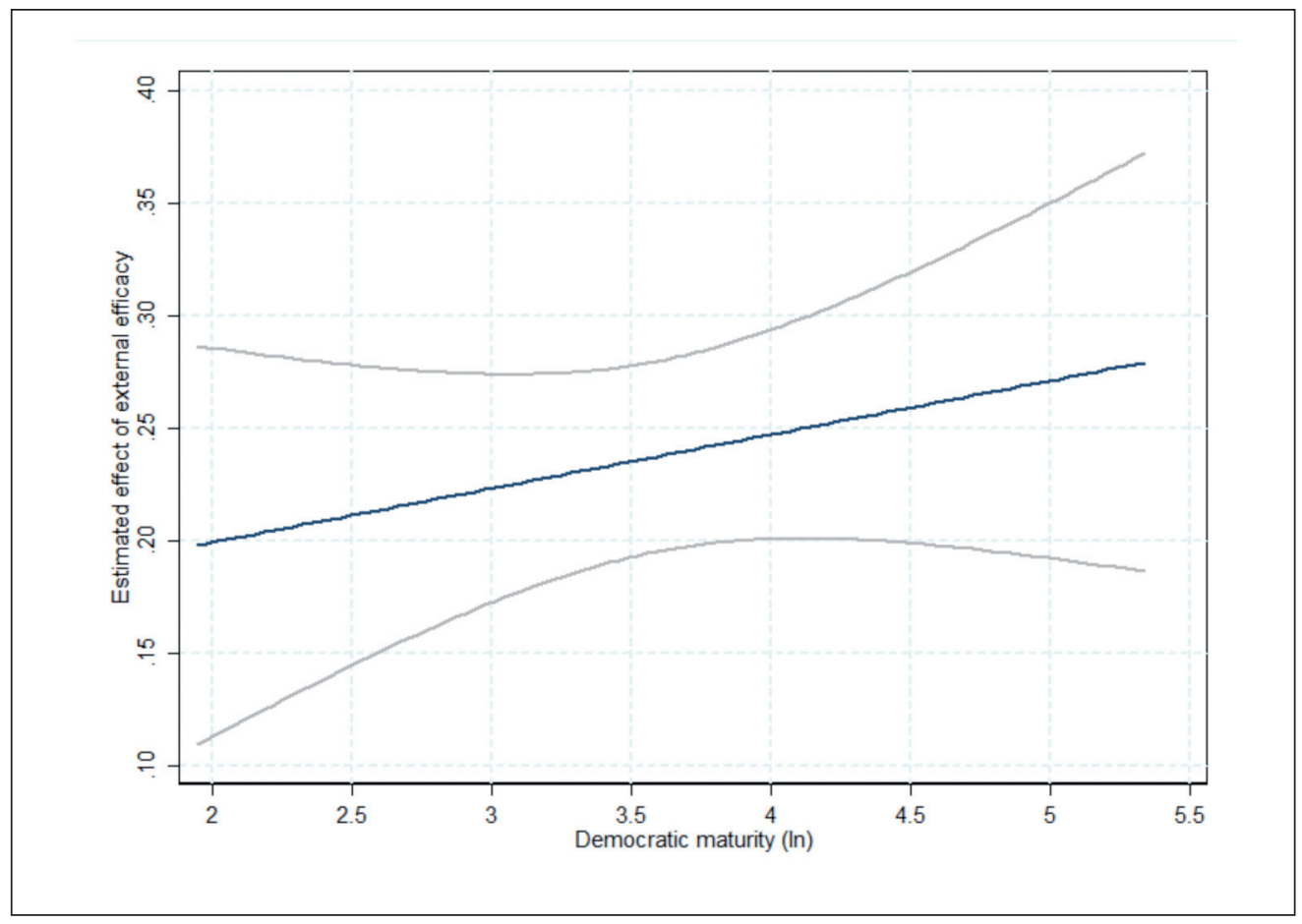

Data sources: CSES III and Polity IV. Project. 95\% confidence interval is displayed.

efficacy is not significant $\left(\beta_{\mathrm{EFF} \mid \mathrm{MATO}}=.027\right) \cdot{ }^{2 \mathrm{II}} \mathrm{But}$ as a democratic regime matures, the impact becomes highly positive. For example, when a democracy has functioned for two decades, the coefficient of external efficacy is at $.219\left(\beta_{\mathrm{EFF} \mid \mathrm{MAT}}=.027+3 \times .064=.219\right) \cdot{ }^{22}$ When a regime is even more stable, say 55 years, the coefficient increases to $.283\left(\beta_{\mathrm{EFF} / \mathrm{MAT} 4}=.027+4 \times .064=.283\right)$ and when the democracy has persisted for nearly 150 years, the coefficient that expresses the impact of external efficacy on self-reported turnout should be at $.347\left(\beta_{\mathrm{EFF} \mid \mathrm{MATS}}=.027+\right.$ $5 \times .064=.347)$.

To portray the interaction graphically, we provide Figure 2 above. In addition to the effect of external efficacy for different values of democratic maturity, this figure shows a $95 \%$ confidence interval for the effect of external efficacy. As can be seen, within the whole interval of real values of democratic maturity - in our dataset, its logarithm varies from I.94 to 5.34 (see Table I), which

2I For instructions on how to interpret interaction terms, see e.g. Kam and Franzese (2007). In Model 4, the coefficient $\beta_{\text {EFF } \mid \text { MATo }}$ can be seen next to the effect of external efficacy. This coefficient no longer expresses the direct effect of external efficacy on propensity to vote, but rather its effect when democratic maturity is equal to o (it is reflected through the mark of the coefficient where the condition MATo is attached).

22 Since the variable that expresses democratic maturity has been logarithmized, at first, we must translate its values to the original form. Thus, the value of 3 corresponds with 20 years with a coherent democracy $(\ln 20=3)$, the value of 4 with 55 years, and the value of 5 with $\mathrm{I} 48$ years. corresponds to the interval of the values from 7 to 208 years - the effect of external efficacy on self-reported turnout appears to be significant (the $95 \%$ confidence interval does not contain zero). Given this result, we can conclude that there is certain empirical evidence that democratic maturity may influence the decision whether to vote not only directly, but it is also able to change the size of the effect of some individual-level variables - in our case, a sense of external efficacy - on self-reported turnout. ${ }^{23}$

\section{Concluding remarks}

Voting occupies a special place in the analysis of political participation. By a substantial margin, it is the most common way in which citizens may influence the political process (e.g. Dalton 20I4). In light of the principle "one person, one vote," it embodies one of the fundamental democratic principles - political equality. But voter turnout in many countries worldwide is surprisingly low and often declining (see Mair 2002; Norris 2002; Franklin 2004 etc.). Hence, the question of why some people cast a ballot while others do not has become very compelling.

23 Another source of support for the contingent effect of democratic age is presented in fixed effects models (see Appendix C), where the interaction term is positive and highly significant. 
There are many sophisticated responses related to this question, and their discussion undoubtedly exceeds the scope of this paper. This study has focused only on the impact of two factors, a sense of external efficacy and democratic maturity, whose importance stems from the expectation that they might be related to each other. Given their interconnection, we have sought to assess not only their direct effects on self-reported turnout, but also whether the effect of the former varies according to the level of the latter. We have hypothesized that due to variation in the nature of political socialization, the positive effect of external efficacy on voting should increase as a democracy matures. To test this contingent effect of democratic age on external efficacy, we have utilized multilevel logistic regression models.

The outcomes of the empirical analysis have demonstrated that those who feel efficacious are more likely to vote than those who do not. However, the impact of external efficacy does not appear to be uniform across contexts. There are those countries in which its effect on self-reported turnout was estimated to be close to null, and thus not significant, but at the same time, some other countries have shown highly a positive and significant effect of external efficacy.

Of course, the cross-national variance in this effect might be ascribed to many context-level factors. Our study has emphasized the role of democratic legacy. To a certain extent, there is empirical evidence that democratic maturity can influence the probability of casting a ballot not only directly, but also contingently, i.e. as an amplifier of the impact of a sense of external efficacy. The results of the analysis have shown that in emerging democracies, those who feel efficacious vote in roughly same proportion as those who do not. But as a democracy matures, the difference in the proportions of voters between these two groups increases. From this point of view, the analysis provides certain support for the initial hypothesis of this paper. Accordingly, we may speculate that a sense of external efficacy has a different nature in older and newer democracies. While in the former, its acquisition straightforwardly leads to active participation in elections, in the latter, it more likely expresses the fact that people are aware that they possess, compared to the situation in the preceding undemocratic regime, an opportunity to influence politics. This non-uniform character of external efficacy in people's minds results primarily from different political socialization and the role of the agents of this process.

However, these outcomes must be evaluated with care. After restriction of the dataset, only twenty-seven countries have been examined, which is not a very high number for multilevel modeling. We have been forced to remove several states due to missing values; in the remainder, very rough data were sometimes utilized (for example, consider the country gaps in actual and selfreported turnout in Appendix A). There is also the ubiquitous problem of omitted-variable bias as well as the difficulty that concerns the operationalization of concepts and the transformation of the variables. All these aspects of our work signify that the results are more or less distorted.

Despite these and many other facts (e.g. Van der Meer et al. 2010), we believe that this paper contributes to the body of literature on voter turnout. It deepens knowledge about how context matters and demonstrates that a comprehensive explanation of one's voting decision should not be frozen in the simple logic of direct effects. Here, some way to move beyond such a position has been offered. Although the results of the analysis are not absolutely satisfactory, it seems that the path we have chosen does not lead down a blind alley.

\section{References}

Abramson, Paul R./John H. Aldrich (1982). The Decline of Electoral Participation in America, in: American Political Science Review, Vol. 76(3), 502-52I.

Acock, Alan C./Harold D. Clarke (1990). Alternative Measures of Political Efficacy: Models and Means, in: Quality \& Quantity, Vol. 24(I), 87-IO5.

Adam Carr's Election Archive (2015). Internet: http://psephos.adam-carr.net/ (accessed 15.3.2015).

Aldrich, John H./Jacob M. Montgomery/Wendy Wood. (20II). Turnout as a Habit, in: Political Behavior, Vol. 33(4), 535-564.

Almond, Gabriel A./Sidney Verba (1963). The Civic Culture: Political Attitudes and Democracy in Five Nations, Princeton.

Anderson, Christopher J. (2007). The Interaction of Structures and Voting Behavior, in: Russell J. Dalton/HansDieter Klingemann: The Oxford Handbook of Political Behavior. New York, 589-609.

Andiuza Perea, Eva (2002). Individual Characteristics, Institutional Incentives and Electoral Abstention in Western Europe, in: European Journal of Political Research, Vol. 4I(5), 643-672.

Balch, George I. (1974). Multiple Indicators in Survey Research: The Concept of 'Sense of Political Efficacy', in: Political Methodology, Vol. I(2), I-43.

Barry, Brian (1970). Sociologists, Economists, and Democracy, Chicago.

Birch, Sarah (2009). Full Participation: A Comparative Study of Compulsory Voting, New York.

Blais, Andre/Agnieszka Dobrzynska (1998). Turnout in electoral democracies, in: European Journal of Political Research, Vol. 33(2), 239-26I. 
Bernhagen, Patrick/Michael Marsh (2007). Voting and Protesting: Explaining Citizen Participation in Old and New European Democracies, in: Democratization, Vol. I4(I), 44-72.

Brambor, Thomas/William Roberts Clark/Matt Golder (2006). Understanding Interaction Models: Improving Empirical Analyses, in: Political Analysis, Vol. I4(I), 63-82.

Brooks, Chris (2008). Introductory Econometrics for Finance, Cambridge.

Bühlmann, Marc/Markus Freitag (2006). Individual and Contextual Determinants of Electoral Participation, in: Swiss Political Science Review, Vol. I2(4), 13-47.

Campbell, Angus/Gerald Gurin/Warren E. Miller (1954). The Voter Decides, Evanston.

Campbell, Angus/Philip Converse/Warren Miller/Donald Stokes (1960). The American Voter, New York.

Comparative Study of Electoral Systems, third module (2015). Internet: www.cses.org (accessed 15.3.2015).

Converse, Philip E. (1972). Change in the American Electorate, in: Angus Campbell/Philip Converse (eds.): The Human Meaning of Social Change, New York, 263-337.

Cox, Gary W./Michael C. Munger (1989). Closeness, Expenditures, and Turnout in the 1982 U.S. House Elections, in: American Political Science Review, Vol. 83(I), 217-23I.

Craig, Stephen C./Michael E. Maggiotto (1982). Measuring Political Efficacy, in: Political Methodology, Vol. 8(3), 85-I09.

Craig, Stephen C./Richard G. Niemi/Glenn E. Silver (1990). Political Efficacy and Trust: A Report on the NES Pilot Study Items, in: Political Behavior, Vol. I2(3), 289-314.

Crewe, Ivor (1976). Party Identification Theory and Political Change in Britain, in: Ian Budge/Ivor Crewe/ Dennis Farlie (eds.): Party Identification and Beyond: Representations of Voting and Party Competition, London, 33-6I.

Dalton, Russell J. (2014). Citizen Politics: Public Opinion and Political Parties in Advanced Industrial Democracies, Los Angeles.

Dalton, Russell J./Christopher J. Anderson (20II). Citizens, Context, and Choice, in: Russell J. Dalton/Christopher J. Anderson (eds.): Citizens, Context, and Choice: How Context Shapes Citizens' Electoral Choices, Oxford, 3-30.

Easton, David (1957). An Approach to the Analysis of Political Systems, in: World Politics, Vol. 9(3), 383-400.

Easton, David/Jack Dennis (1967). The Child's Acquisition of Regime Norms: Political Efficacy, in: American Political Science Review, Vol. 6I(I), 25-38.

Endersby, James W./Jonathan T. Krieckhaus (2008). Turnout around the globe: The influence of electoral insti- tutions on national voter participation, $1972-2000$, in: Electoral Studies, Vol. 27(4), 60I-6Io.

Franklin, Mark N. (2004). Voter Turnout and the Dynamics of Electoral Competition in Established Democracies since 1945 , Cambridge.

Fieldhouse, Edward/Mark Tranmer/Andrew Russell (2007). Something about Young People or Something about Elections? Electoral Participation of Young People in Europe: Evidence from a Multilevel Analysis of the European Social Survey, in: European Journal of Political Research, Vol. 46(6), 797-822.

Gallego, Aina (2010). Understanding Unequal Turnout: Education and Voting in Comparative Perspective, in: Electoral Studies, Vol. 29(2), 239-248.

Gallego, Aina (2015). Unequal Political Participation Worldwide, New York.

Galston, William A. (200I). Political knowledge, political engagement, and civic education, in: Annual Review of Political Science, Vol. 4, 217-234.

Gelman, Andrew/Jennifer Hill (2007). Data Analysis Using Regression and Multilevel/Hierarchical Models, Cambridge.

Geys, Benny (2006). Explaining voter turnout: A review of aggregate-level research, in: Electoral Studies, Vol. 25(4), 637-663.

Gimpel, James G./Celeste J. Lay/Jason E. Schuknecht (2003). Cultivating Democracy: Civic Environments and Political Socialization in America, Washington.

Green, Donald P./Ron Shachar (2000). Habit Formation and Political Behaviour: Evidence of Consuetude in Voter Turnout, in: British Journal of Political Science, Vol. 30(4), 56I-573.

Grönlund, Kimmo/Maija Setälä (2007). Political Trust, Satisfaction and Voter Turnout, in: Comparative European Politics, Vol. 5(4), 400-422.

Gurr, Ted R. (1974). Persistence and Change in Political Systems, I800-I97I, in: American Political Science Review, Vol. 68(4), I482-I5O4.

Hadjar, Andreas/Michael Beck (2010). Who Does Not Participate in Elections in Europe and Why Is This? A multilevel analysis of social mechanisms behind non-voting, in: European Societies, Vol. I2(4), $52 \mathrm{I}-542$.

Heath, Oliver (2007). Explaining Turnout Decline in Britain, 1964-2005: Party Identification and Political Context, in: Political Behavior, Vol. 29(4), 493-516.

Hox, Joop J. (20I0). Multilevel analysis. Techniques and applications, New York.

Hyman, Herbert H. (1959). Political Socialization: a Study in the Psychology of Political Behavior, Glencoe.

International IDEA - International Institute for Democracy and Electoral Assistance (2015). Voter Turnout Data. Internet: www.idea.int (accessed 15.3.2015). 
Iyengar, Shato. (1980). Subjective Political Efficacy as a Measure of Diffuse Support, in: The Public Opinion Quarterly, Vol. 44(2), 249-256.

Jackman, Robert W./Ross A. Miller (2004). Before Norms: Institutions and Civic Culture, Ann Arbor.

Jaggers, Keith/Ted R. Gurr (1995). Tracking Democracy's Third Wave with the Polity III Data, in: Journal of Peace Research, Vol. 32(4), 469-482.

Janák, Dušan/Robert Klobucký (2014a). Co bychom věděli o sociologii, kdybychom četli pouze Sociologický časopis a Sociológii? Obsahová analýza dvou sociologických periodik od "sametové revoluce“ do současnosti, in: Sociologický časopis, Vol. 50(5): 645-670.

Janák, Dušan/Robert Klobucký (20I4b). The issue of Central Europe in the main Czech and Slovak sociological journals Sociologický časopis/Czech Sociological Review and Sociológia/Slovak Sociological Review between 1990 and 2000, in: Socio.hu, Vol. 4(2): 74-95. Internet: http://socio.hu/uploads/files/ Visegrad/5janak_klobucky.pdf (accessed I3.6.2015).

Jennings, M. Kent (2007). Political Socialization, in: Russell J. Dalton/Hans-Dieter Klingemann (eds.): The Oxford Handbook of Political Behavior, Oxford, 29-44.

Jusko, Karen L./Phillips W. Shively (2005). Applying a Two-Step Strategy to the Analysis of Cross-National Public Opinion Data, in: Political Analysis, Vol. I3(4), 327-344.

Kam, Cindy D./Robert J. Franzese (2007). Modeling and Interpreting Interactive Hypotheses in Regression Analysis, Ann Arbor.

Karp, Jeffrey A./Susan A. Banducci (2007). Party Mobilization and Political Participation in New and Old Democracies, in: Party Politics, Vol. 13(2), 217-234.

Karp, Jeffrey A./Susan A. Banducci (2008). Political Efficacy and Participation in Twenty-Seven Democracies: How Electoral Systems Shape Political Behaviour, in: British Journal of Political Science, Vol. 38(2), 3II-334.

Kittilson, Miki C./Christopher J. Anderson (2OII). Electoral Supply and Voter Engagement, in: Russell J. Dalton/ Christopher J. Anderson (eds.): Citizens, Context, and Choice: How Context Shapes Citizens' Electoral Choices, Oxford, 33-54.

Kostadinova, Tatiana (2003). Voter turnout dynamics in post-communist Europe, in: European Journal of Political Research, Vol. 42(6), 74I-759.

Kostadinova, Tatiana (2009). Abstain or Rebel: Corruption Perceptions and Voting in East European Elections, in: Politics \& Policy, Vol. 37(4), 69I-7I4.

Ladner, Andreas/Henry Milner (1999). Do Voters Turn Out More under Proportional than Majoritarian Systems? The Evidence from Swiss Communal Elections, in: Electoral Studies, Vol. I9(2), 235-250.
Leighley, Jan E./Jonathan Nagler (1992). Individual and Systemic Influences on Turnout: Who Votes? 1984, in: Journal of Politics, Vol. 54(3), 718-740.

Mair, Peter (2002). In the Aggregate: Mass Electoral Behaviour in Western Europe, 1950-2000, in: Hans Keman (ed.): Comparative Democratic Politics, London, I22-I42.

Marshall, Monty G./Ted R. Gurr/Keith Jaggers (20II). Polity IV Project. Political Regime Characteristics and Transitions, I800-20I0. Dataset Users' Manual, Vienna, VA.

Matsusaka, John J. (1993). Election Closeness and Voter Turnout: Evidence from California Ballot Propositions, in: Public Choice, Vol. 76(4), 313-334.

McPherson, J. Miller/Susan Welch/Cal Clark (1977). The Stability and Reliability of Political Efficacy: Using Path Analysis to Test Alternative Models, in: American Political Science Review, Vol. 71(2), 509-52I.

Mishler, William/Richard Rose (200I). What Are the Origins of Political Trust? Testing Institutional and Cultural Theories in Post-communist Societies, in: Comparative Political Studies, Vol. 34(I), 30-62.

Muller, Edward N./Mitchell A. Seligson (1994). Civic Culture and Democracy: The Question of Causal Relationships, in: American Political Science Review, Vol. 88(3), 635-652.

Nohlen, Dieter (2002). Political Participation in New and Old Democracies, in: Rafael López-Pintor/Maria Gratschew (eds.): Voter Turnout since 1945: A Global Report, Halmstad, I3-19.

Norris, Pippa (2002). Democratic Phoenix: Reinventing Political Activism, Cambridge.

Norris, Pippa (2004). Electoral engineering: voting rules and political behavior, Cambridge.

Norris Pippa/Stefaan Walgrave/Peter Van Aelst (2005) Who Demonstrates? Antistate Rebels, Conventional Participants, or Everyone?, in: Comparative Politics, Vol. 37(2), I89-205.

Nový, Michal (20I3). Volební účast a její determinanty ve starých a nových demokraciích Evropy, in: Sociológia, Vol. 45(2), 195-228.

Pacek, Alexander C./Grigore Pop-Eleches/Joshua A. Tucker (2009). Disenchanted or Discerning: Voter Turnout in Post-Communist Countries, in: Journal of Politics, Vol. 7I(2), 473-49I.

Pacheco, Julianna S. (2008). Political Socialization in Context: The Effect of Political Competition on Youth Voter Turnout, in: Political Behavior, Vol. 30(4), 415-436.

Panagopoulos, Costas (2008). The Calculus of Voting in Compulsory Voting Systems, in: Political Behavior, Vol. 30(4), 455-467.

Parties and Elections in Europe (2015). Internet: http://www. parties-and-elections.eu/ (accessed 15.3.2015). 
Pasek, Josh/Lauren Feldman/Daniel Romer/Kathleen Hall Jamieson (2008). Schools as Incubators of Democratic Participation: Building Long-Term Political Efficacy with Civic Education, in: Applied Development Science, Vol. I2(I): 26-37.

Platt, Matthew B. (2008). Participation for What? A Policy-Motivated Approach to Political Activism, in: Political Behavior, Vol. 3O(3), 39I-4I3.

Pop-Eleches, Grigore/Joshua A. Tucker (20II). Communism's shadow: Postcommunist legacies, values, and behaviour, in: Comparative Politics, Vol. 43(4), 379-408.

Pop-Eleches, Grigore/Joshua A. Tucker (2014). Communist socialization and post-communist economic and political attitudes, in: Electoral Studies, Vol. 33, 77-89.

Pollock, Philip H. (I983). The Participatory Consequences of Internal and External Political Efficacy: A Research Note, in: Western Political Quarterly, Vol. 36(3), 400-409.

Quintelier, Ellen/Marc Hooghe/Sofie Marien (2011). The Effect of Compulsory Voting on Turnout Stratification Patterns: A Cross-national Analysis, in: International Political Science Review, Vol. 32(4), 396-4I6.

Rabe-Hesketh, Sophia/Anders Skrondal (20I2). Multilevel and longitudinal modeling using Stata, College Station.

Rocha, Rene R./Caroline J. Tolbert/Daniel C. Bowen/ Christopher J. Clark (20IO). Race and Turnout: Does Descriptive Representation in State Legislatures Increase MinorityVoting?, in: Political Research Quarterly, Vol. 63(4), 890-907.

Rose, Richard (2009). Understanding post-communist transformation: a bottom up approach, New York.

Rosenstone, Steven J./John M. Hansen (2003). Mobilization, Participation, and Democracy in America, New York.

Sapiro, Virginia (2004). Not your Parents' Political Socialization: Introduction for a New Generation, in: Annual Review of Political Science, Vol. 7, I-23.

Sigel, Roberta (1970). Assumptions about the Learning of Political Values, in: Edward S. Greenberg (ed.): Political Socialization, New York, 19-23.

Sigelman, Lee (1982). The Nonvoting Voter in Voting Research, in: American Journal of Political Science, Vol. 26(I), 47-56.
Singh, Shane (201I). Contradictory Calculi: Differences in Individuals' Turnout Decisions across Electoral Systems, in: Political Research Quarterly, Vol. 64(3), $646-655$.

Smets, Kaat/Carolien van Ham (2013). The Embarrassment of Riches? A Meta-Analysis of Individual-Level Research on Voter Turnout, in: Electoral Studies, Vol. 32(2), 344-359.

Söderlund, Peter/Hanna Wass/Andre Blais (20II). The impact of motivational and contextual factors on turnout in first- and second-order elections, in: Electoral Studies, Vol. 30(4), 689-699.

Tingsten, Herbert (1937). Political Behaviour: Studies in Election Statistics, London.

Van der Meer, Tom/Manfred Te Grotenhuis/Ben Pelzer (2010). Influential Cases in Multilevel Modeling: A Methodological Comment, in: American Sociological Review, Vol. 75(I), I73-I78.

Verba, Sidney/Kay L. Schlozman/Henry E. Brady (I995). Voice and Equality: Civic Voluntarism in American Politics, Cambridge.

Verba, Sidney/Norman Nie (1972). Participation in America: Political Democracy and Social Equality, New York.

Wolfinger, Raymond E./Steven J. Rosenstone (1980). Who Votes?, New Haven.

\section{Authors}

Michal Nový works as a researcher at the International Institute of Political Science, Masaryk University. He has a Ph.D. in Political Science from Masaryk University and an M.Sc. in Regional Development from Mendel University in Brno. His research focuses on political behavior and public administration.

Tomáš Katrňák is an Associate Professor of Sociology at the Faculty of Social Studies, Masaryk University. His research interests are social stratification, class analysis, marriage market, social statistics and categorical data analysis. 


\section{Appendices}

Appendix A: Proportion of people that voted in twenty-seven countries

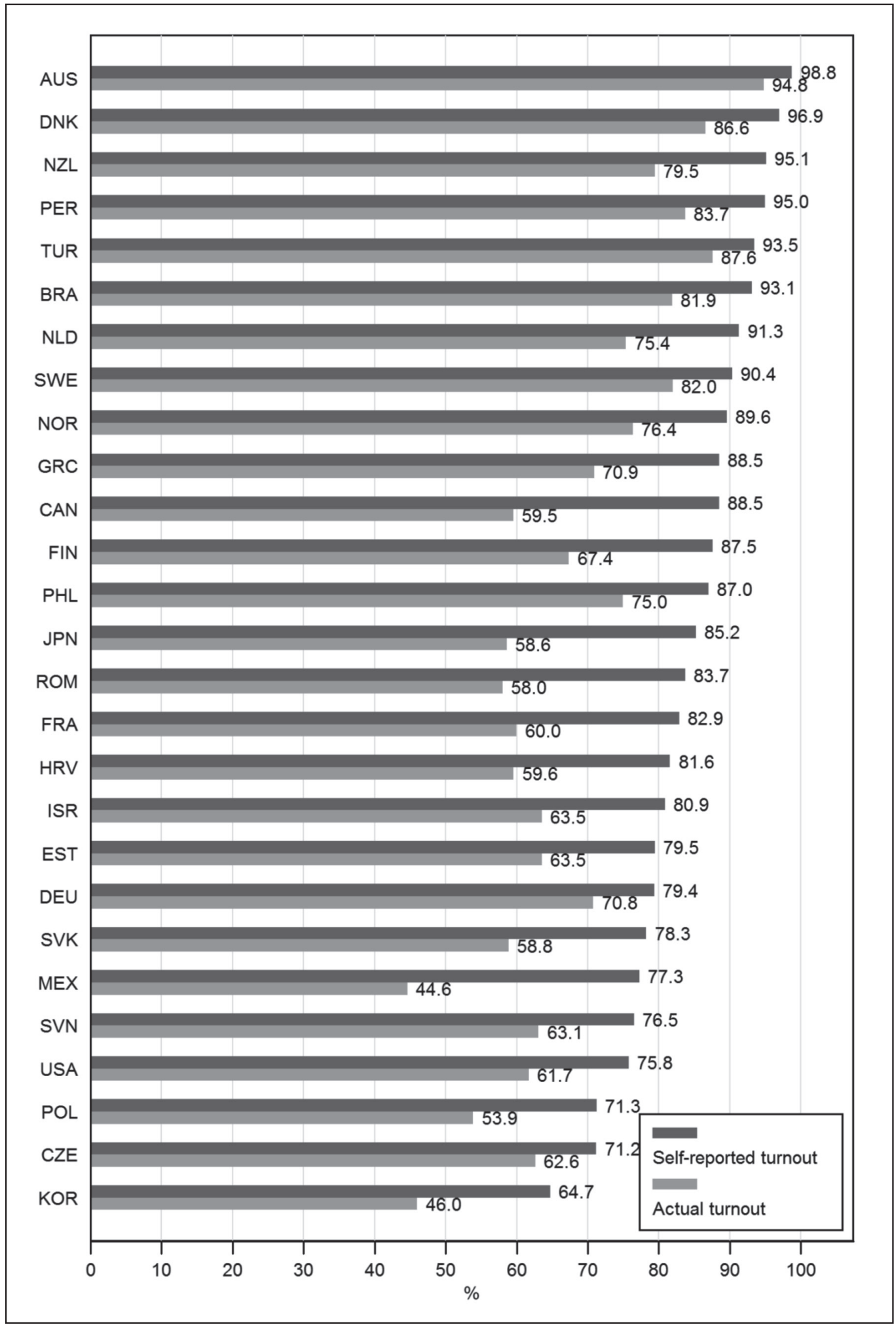

Data sources: CSES III and International IDEA. Actual turnout is measured as a proportion of registered voters who cast a ballot. When the intersection between parliamentary and presidential elections occurs, the figure shows actual turnout in parliamentary elections. 
Appendix B: Variables included in the analysis

\begin{tabular}{|c|c|c|c|}
\hline Variable & CSES item & Question wording / description & Values after transformation \\
\hline \multicolumn{4}{|l|}{ Individual level } \\
\hline $\begin{array}{l}\text { Participation in } \\
\text { election }\end{array}$ & C3021_1 & (The wording follows national standards) & $\begin{array}{l}1 \text { - voted, } \\
0 \text { - not voted }\end{array}$ \\
\hline External efficacy & C3005 & $\begin{array}{l}\text { Some people say that no matter who people } \\
\text { vote for, it won't make any difference to what } \\
\text { happens. Others say that who people vote for } \\
\text { can make a big difference to what happens. } \\
\text { Using the scale on this card (where one means } \\
\text { that voting won't make any difference to what } \\
\text { happens and five means that voting can make } \\
\text { a big difference), where would you place } \\
\text { yourself? }\end{array}$ & $\begin{array}{l}1 \text { - who people vote for will not } \\
\text { make any difference, } 5 \text { - who } \\
\text { people vote for can make a big } \\
\text { difference }\end{array}$ \\
\hline Age & C2001 & - & Years \\
\hline Education & C2003 & - & $\begin{array}{l}1 \text { - tertiary, } 0 \text { - others (primary, } \\
\text { vocational training, secondary) }\end{array}$ \\
\hline Party identification & C3020_1 & $\begin{array}{l}\text { Do you usually think of yourself as close to any } \\
\text { particular party? }\end{array}$ & $\begin{array}{l}1 \text { - identified with a party, } 0 \text { - not } \\
\text { identified }\end{array}$ \\
\hline $\begin{array}{l}\text { Satisfaction with } \\
\text { democracy }\end{array}$ & C3019 & $\begin{array}{l}\text { On the whole, are you very satisfied, fairly } \\
\text { satisfied, not very satisfied, or not at all } \\
\text { satisfied with the way democracy works in } \\
\text { (country)? }\end{array}$ & $\begin{array}{l}1 \text { - satisfied (very or fairly satisfied), } \\
0 \text { - not satisfied (not very satisfied } \\
\text { or not at all satisfied) }\end{array}$ \\
\hline $\begin{array}{l}\text { Campaign } \\
\text { involvement }\end{array}$ & C3018 & $\begin{array}{l}\text { How closely did you follow the election } \\
\text { campaign? Very closely, fairly closely, not very } \\
\text { closely, or not closely at all? }\end{array}$ & $\begin{array}{l}1 \text { - closely followed (very closely } \\
\text { or fairly closely), } 0 \text { - not closely } \\
\text { followed (not very closely or not } \\
\text { closely at all) }\end{array}$ \\
\hline Marital status & C2004 & - & $\begin{array}{l}1 \text { - married or living together as } \\
\text { married, } 0 \text { - others }\end{array}$ \\
\hline Union membership & C2005 & - & 1 - member, 0 - non-member \\
\hline Previous election & C3031 & (The wording follows national standards) & $\begin{array}{l}1 \text { - voted } \\
0-\text { not voted }\end{array}$ \\
\hline
\end{tabular}




\begin{tabular}{|c|c|c|c|}
\hline Variable & CSES item & Question wording / description & Values after transformation \\
\hline \multicolumn{4}{|l|}{ Contextual level } \\
\hline Democratic maturity & - & $\begin{array}{l}\text { The number of years through election analyzed } \\
\text { in the survey during which a democracy scored } \\
+7 \text { to }+10 \text { in Polity score without any interruption }\end{array}$ & Natural logarithm of years \\
\hline Electoral salience & C1015, C5054 & $\begin{array}{l}\text { The variable measures how much was at stake in } \\
\text { the election that concerns the CSES survey }\end{array}$ & $\begin{array}{l}2 \text { - highly salient election } \\
\text { (parliamentary election in } \\
\text { parliamentary regime, presidential } \\
\text { election in presidential regime, } \\
\text { simultaneous elections in } \\
\text { parliamentary or presidential } \\
\text { regime), } 1 \text { - mean salient election } \\
\text { (parliamentary or presidential } \\
\text { elections in mixed regime), } 0 \text { - } \\
\text { lowly salient election (presidential } \\
\text { election in parliamentary regime, } \\
\text { parliamentary election in } \\
\text { presidential regime) }\end{array}$ \\
\hline Compulsory voting & C5044 & - & $\begin{array}{l}1 \text { - yes (the law states that those } \\
\text { who have the right to vote are } \\
\text { obliged to exercise that right), } 0 \text { - } \\
\text { no }\end{array}$ \\
\hline $\begin{array}{l}\text { Closeness of } \\
\text { election }\end{array}$ & - & $\begin{array}{l}\text { Victory margin (i.e. the difference in vote shares } \\
\text { between the winning party/candidate and the } \\
\text { second most successful party/candidate) }\end{array}$ & $\begin{array}{l}\text { The percentage of victory margin } \\
\text { (calculated from the databases of } \\
\text { Parties and elections in Europe and } \\
\text { Adam Carr's election archive) }\end{array}$ \\
\hline PR & C5058 & The use of proportional electoral system & $1-$ yes, $0-$ no \\
\hline GDP per capita & C5081_1 & $\begin{array}{l}\text { The indicator of state's economic performance } \\
\text { in the election year }\end{array}$ & Natural logarithm of GDP per capita \\
\hline
\end{tabular}




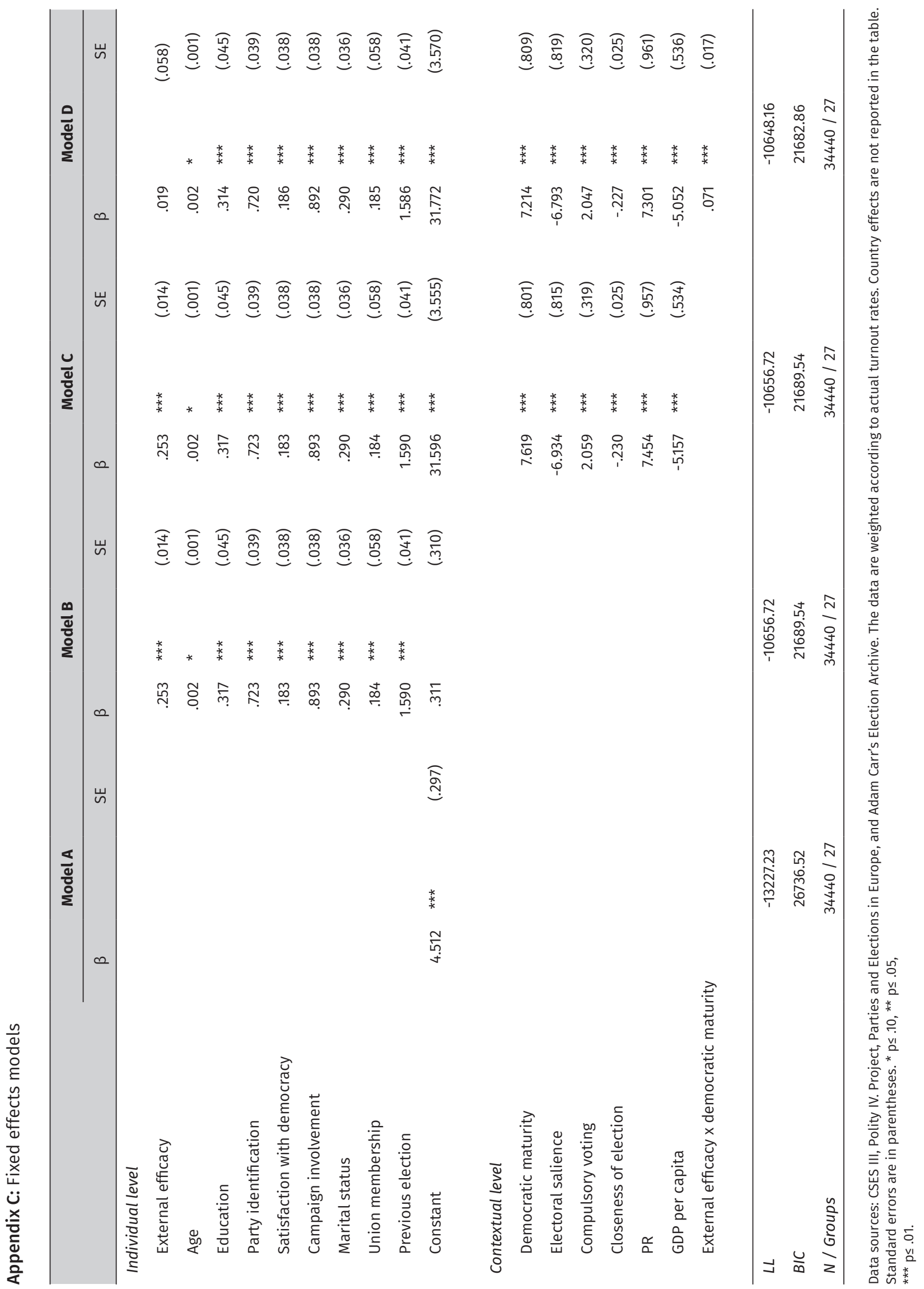

